dr hab. Ryta Iwona DZIEMIANOWICZ, prof. UwB

Wydział Ekonomii i Zarzadzania, Uniwersytet w Białymstoku e-mail: r.dziemianowicz@uwb.edu.pl

ORCID: 0000-0002-7755-9887

\author{
dr Aneta KARGOL-WASILUK \\ Wydział Ekonomii i Zarzadzania, Uniwersytet w Białymstoku \\ e-mail: a.kargol@uwb.edu.pl \\ ORCID: 0000-0003-1915-2840
}

dr hab. Artur BOLTROMIUK, prof. UwB

Wydział Ekonomii i Zarzadzania, Uniwersytet w Białymstoku e-mail: a.boltromiuk@uwb.edu.pl

ORCID: 0000-0002-6113-7153

DOI: $10.15290 /$ oes.2018.04.94.16

\title{
SAMODZIELNOŚĆ FINANSOWA GMIN W POLSCE W KONTEKŚCIE KONCEPCJI GOOD GOVERNANCE
}

\section{Streszczenie}

Cel - Celem artykułu jest analiza zakresu samodzielności finansowej gmin w Polsce w kontekście koncepcji good governance (jakość rządzenia). Artykuł jest próbą odpowiedzi na pytanie o to, czy zakres przedmiotowej samodzielności jest spójny z wymiarami jakości rząazenia?

Metody - W artykule zastosowano metodę opisową z elementami analizy prawnej oraz analizy danych statystycznych dotyczących sytuacji budżetowej gmin w Polsce w latach 2008-2017.

Opis badań - Przedmiotem rozważań prowadzonych w artykule są zagadnienia samodzielności finansowej JST w Polsce w zestawieniu $\mathrm{z}$ istota good governance). W poszczególnych częściach artykułu autorzy przedstawili teoretyczno-prawne aspekty samodzielności finansowej JST, dokonali charakterystyki koncepcji good governance oraz podjęli próbę oceny zakresu samodzielności finansowej gmin w Polsce przez pryzmat wymiarów jakości rządzenia.

Wyniki - Stwierdzono, że samodzielność finansowa gmin nie jest kategorią stałą. Mimo procesu decentralizacji jest ona ograniczona w różnorodny sposób, co wynika m.in. z działań państwa na szczeblu centralnym, a także jest zdeterminowana stanem finansów danej jednostki. Analizując zakres samodzielności finansowej gmin w perspektywie good governance dostrzeżono, że w niewielkim stopniu jest ona spójna z wymiarami jakości rządzenia, takimi jak: demokratyczne państwo prawne, przejrzystość, partnerstwo oraz efektywność i skuteczność.

Słowa kluczowe: gmina, samodzielność finansowa, good governance 


\section{FINANCIAL AUTONOMY OF POLISH COMMUNES AND GOOD GOVERNANCE}

\section{Summary}

Goal - The purpose of the paper is to analyse the degree (the scope) of financial autonomy of Polish communes from the perspective of good governance. The authors attempt to answer the following question: Is the extent of financial autonomy of communes consistent with the scope of good governance?

Methods - The paper uses a descriptive method with elements of the legal analysis and the statistical analysis of data regarding the budgetary standing of Polish communes in the years 2008-2017.

Approach -This paper investigates issues associated with the financial autonomy of Polish local government units (LGUs) in terms of good governance. In the respective sections of the paper, the authors present the theoretical and legal aspects of LGUs' financial self-reliance, examine the concept of good governance, analyse the financial situation of Polish communes, and attempt to assess the extent of their financial autonomy from the perspective of the various aspects of good governance.

Findings - It is possible to conclude that financial autonomy of communes is not a fixed category. Despite the process of decentralisation, it is constrained by a number of different factors (e.g. the activity of state authorities) and determined by the financial standing of individual LGUs. The analysis of the scope of communes' financial autonomy reveals that it is moderately correlated with such aspects of good governance as: the rule of law, transparency, efficiency, effectiveness, partnership.

Słowa kluczowe: commune, financial independence, good governance

JEL classification: H6, H61, H11

\section{Wstęp}

Samodzielność finansowa ${ }^{1}$ gmin w Polsce jest w literaturze przedmiotu stosunkowo często przedmiotem analizy, zarówno w ujęciu prawnym, jak i ekonomicznym $^{2}$, jednakże prowadzi się niewiele badań, które odnoszą się do możliwości zastosowania koncepcji good governance $\mathrm{w}$ sferze samorzą dowej. Przedmiotem rozważań prowadzonych $\mathrm{w}$ artykule są zagadnienia samodzielności finansowej gmin w Polsce, w powiązaniu z istotą koncepcji good governance.

Celem artykułu jest analiza zagadnienia samodzielności finansowej gmin w Polsce, w tym próba określenia stopnia, w jakim przedmiotowa samodzielność może być analizowana w kontekście koncepcji good governance. Artykuł jest również próbą odpowiedzi na pytanie o to, czy zakres przedmiotowej samodzielności jest spójny z wymiarami jakości rządzenia? Odpowiedź na tak sformułowane pytanie

1 W literaturze anglojęzycznej częściej używa się określenia autonomia finansowa [por. Poniatowicz, 2018].

2 Zob. badania takich autorów jak: B. Filipiak [2011]; M. Jastrzębska [2012]; L. Patrzałek [2010]; K. Piotrowska-Marczak [1997]; E. Kornberger-Sokołowska [2001a]; M. Miemiec i in. [2013]; E. Ruśkowski [2007]; C. Kosikowski, J. Salachna [2012]; P. Swianiewicz [2011]; K. Surówka [2013] $i$ in. 
może posłużyć do oceny jakości rządzenia w sferze finansowej na poziomie gminnym.

W artykule zastosowano metodę opisową z elementami analizy prawnej oraz analizy danych statystycznych dotyczących wybranych elementów sytuacji budżetowej gmin w Polsce w latach 2008-2017. Dane statystyczne wykorzystane w badaniu pochodziły z Głównego Urzędu Statystycznego, w tym z Banku Danych Lokalnych oraz $\mathrm{z}$ agend rządowych, takich jak: Ministerstwo Rozwoju, Ministerstwo Administracji i Cyfryzacji, Ministerstwo Spraw Wewnętrznych i Administracji.

\section{Charakterystyka koncepcji good governance}

Według definicji sformułowanej przez Bank Światowy governance oznacza sposób, w jaki sprawuje się władzę w zakresie zarządzania ekonomicznymi i społecznymi zasobami na rzecz rozwoju [The World Bank, 1992]. Współcześnie governance utożsamia się najczęściej z procesem podejmowania decyzji oraz procesem ich wdrażania. Przedmiotowe pojęcie może być wykorzystywane w różnych kontekstach, np.: corporate governance, international governance, national governance, public governance czy też local governance. Przyjmując przytoczoną definicję jako punkt wyjścia do dalszych analiz identyfikuje się grupy formalnych i nieformalnych aktorów zaangażowanych w proces rządzenia, a także formalne i nieformalne struktury, które są ustanawiane w celu podjęcia i wdrożenia określonych decyzji. Jednym z podmiotów rządzenia jest rząd, inni aktorzy zaangażowani $\mathrm{w}$ proces rządzenia różnią się zależnie od poziomu, którego on dotyczy. Wszystkie zaangażowane podmioty, inne niż rząd i wojsko, stanowią element społeczeństwa obywatelskiego [What is good governance?].

Wielu zagranicznych badaczy podejmowało i nadal podejmuje próby analizy koncepcji governance. Na przykład O.E. Williamsonowi zawdzięczamy rozumienie przedsiębiorstwa jako governance structure. Ponadto wskazuje on na instytucje governance, takie jak: rynek, hierarchia, bybrids, bureaus [Williamson, 1996]. Z kolei R.A.W. Rhodes przyjmuje, że governance dotyczy samoorganizujących się sieci międzyorganizacyjnych, które uzupełnione o rynek i hierarchię jako struktury rządzenia, podstawiane są $\mathrm{w}$ miejsce autorytatywnie alokowanych zasobów oraz wykonywania kontroli i koordynacji [Rhodes, 1996, s. 652]. Do grona znanych badaczy zjawiska należą również: J.S. Nye, J.D. Donahue [2000]; D. Rodrik [2000]; A.M. Kjaer [2004]; D. Levi-Faur [2012]; B. G. Peters [2012]; B. Jessop; G. Stoker; J. Rosenau; A. Dunsire; B.F. Dollery; J.L. Wallis $i$ in. [por. Hausner $i$ in., 2016].

W Polsce zespół badawczy pod kierunkiem J. Wilkina na początku drugiej dekady XXI wieku pracował nad określeniem warunków jakości rządzenia w sferze wydatków publicznych. Wymieniony autor stwierdza, że „Istota governance jest tworzenie ładu instytucjonalnego, w ramach którego przebiega działalność gospodarcza $\mathrm{i}$ inne formy działalności człowieka. Governance jest zawsze w jakimś zakresie procesem rządzenia, a więc funkcją sprawowania władzy, czyli tego, co było sednem pojęcia governing. Różni się jednak od tego ostatniego wieloma cechami. Governance opiera się na współrządzeniu; zakłada udział „podwładnych” w tworzeniu ładu 
instytucjonalnego, ich aktywność i zaangażowanie w rozwiązywanie problemów koordynacji, organizowania i zarządzania" [Jakość rzqdzenia..., 2013, s. 21]. Równie interesujące analizy w tym zakresie prowadzi zespół J. Hausnera, który podnosi, że koncepcja governance ,jest niezbędnym składnikiem nowoczesnej teorii zarządzania publicznego. Ma ona sens i jest praktycznie przydatna, pod warunkiem jednak, że wpisujemy ją w rekonstrukcję państwa - teoretyczną i praktyczną. Jest zbędna na gruncie weberowskiej teorii państwa i niebezpieczna, jeśli ma być jej ekwiwalentem” [Hausner, 2015, s. 37].

Ukazując istotę good governance, zazwyczaj identyfikuje się różne wymiary jakości rządzenia, np.: partycypacja, dążenie do zgody, odpowiedzialność, przejrzystość, responsywność, skuteczność i efektywność, sprawiedliwość i inkluzywność, praworządność. Te zasady mają zapewnić minimalizację korupcji, dbanie o interesy różnych grup społecznych, a także tych, którzy są najsłabsi [What is good governance?]. W dokumentach Banku Światowego, formułując koncepcję good governance w 1992 r., wskazano na cztery kluczowe obszary, takie jak: zarządzanie sektorem publicznym, odpowiedzialność, prawne ramy rozwoju, informacja i przejrzystość [The World Bank, 1992].

W 2001 r. Komisja Europejska, dostrzegając wage good governance, zaproponowała w Białej Księdze „European Governance” pięć głównych wymiarów, które są ważne dla ustanowienia bardziej demokratycznego sposobu rządzenia. Należą do nich [European Governance ..., 2001]:

1. Otwartość/przejrzystość - instytucje publiczne powinny funkcjonować w bardziej przejrzysty sposób.

2. Partycypacja - zaangażowanie społeczeństwa w proces rządzenia, na wszystkich poziomach władzy publicznej (tzw. dialog obywatelski oraz dialog społeczny).

3. Rozliczalność - precyzyjne określenie zakresu odpowiedzialności poszczególnych instytucji.

4. Skuteczność - poprawa potencjału administracyjnego w zakresie skutecznego i sprawnego realizowania celów polityk publicznych.

5. Spójność - integracja zarządzania różnymi politykami publicznymi, zarówno europejskimi, jak i krajowymi, a także między różnymi poziomami władzy publicznej.

Każda z tych zasad jest niezwykle ważna, jednak nie realizuje się ich odrębnie. Ich stosowanie wzmacniaja dwie dodatkowe zasady: zasada proporcjonalności, która zakłada, że instrumenty dostarczania usług i polityk publicznych będą proporcjonalne do zakładanych celów oraz zasada subsydiarności (pomocniczości), według której działania wyższego poziomu administracji są jedynie pomocnicze względem działań realizowanych na niższych poziomach zarządzania.

Niewatpliwie koncepcja good governance wywodzi się z liberalnego myślenia o rządzie i społeczeństwie. Przyjmując perspektywę neoliberalną, good governance jest ogólnym terminem efektywnego zagospodarowania aktywności obywatelskiej i konsumenckiej społeczeństwa - zależy od „uwolnienia społeczeństwa” w przeciwieństwie do intensyfikacji bezpośrednich działań rządu. Państwo jest w dalszym ciągu 
postrzegane jako główny orkiestrator i oczekuje się, że użyje swojej siły, aby zablokować formy działania niezgodne z zasadami neoliberalnymi [Magnusson, 2015, s. 113]. W świetle dotychczasowych rozważań należy stwierdzić, że koncepcja good governance nie jest precyzyjnie zdefiniowana i zoperacjonalizowana, zatem konieczne jest dokonanie autorskiego wyboru kryteriów, według których samodzielność finansowa gmin w Polsce zostanie poddana krytycznej analizie pod kątem wpisywania się $\mathrm{w}$ koncepcję good governance. Autorzy, biorąc pod uwage użyteczność, a także zasadność oceny samodzielności finansowej gmin w Polsce przez pryzmat wymiarów jakości rządzenia, skupili się na takich wymiarach, jak: demokratyczne państwo prawne, przejrzystość, partnerstwo, efektywność i skuteczność, pomijając pozostałe zasady.

\section{Samodzielność finansowa jednostek samorządu terytorialnego}

Samorząd terytorialny jest swoistą manifestacją konstytucyjnej idei demokracji rozumianej jako rządzenie przez naród. U. Sadioglu, K. Dede podkreślaja, że: „Lokalny rząd kładzie fundamenty dla demokratycznego „samorządzenia” społecznością i terytorium w państwie narodowym" [Sadioglu, Dede, 2016, s. 68]. W świetle Europejskiej Karty Samorządu Terytorialnego: „Samorząd terytorialny oznacza prawo i rzeczywistą zdolność wspólnot lokalnych do regulowania i zarządzania, w ramach prawa, na ich własną odpowiedzialność i na rzecz ich ludności, istotną częścią spraw publicznych" [EKST].

Precyzując zatem przedmiotowe ujęcie w warunkach polskich należy zgodzić się z S. Kańduła, że „samorząd terytorialny jest związkiem publiczno-prawnym, utworzonym przez państwo i wyposażonym we władztwo administracyjne, a do jego zadań należą wszystkie sprawy publiczne niezastrzeżone w Konstytucji RP i ustawach szczegółowych dla innych podmiotów" [Kańduła, 2003, s. 11]. W takim ujęciu istotą możliwości „samorządzenia” jest posiadanie niezbędnych zasobów finansowych, co więcej, jego podstawą jest samodzielność w przedmiotowej sferze.

Samodzielność finansowa to swoista immanencja i kluczowa wartość samorządności terytorialnej. Stanowi jedną z priorytetowych zasad finansów samorządowych, a jej sedno wyraża się w procesie decentralizacji finansów publicznych, która polega na przekazywaniu na rzecz JST odpowiednich zasobów pieniężnych i władztwa do ich rozdysponowania [Devas i in., 2008, s. 11]. Sam zakres samodzielności władzy lokalnej może być jednak w poszczególnych państwach zróżnicowany, stanowiąc pochodna funkcji wypełnianych przez władzę publiczną oraz sposobu i proporcji ich podziału między władzę centralną a lokalną [Kornberger-Sokołowska, 2001, s. 101]. Według R.A. Musgrave władze lokalne powinny być w szerszym zakresie zaangażowane $\mathrm{w}$ realizację funkcji alokacyjnej finansów publicznych, natomiast funkcja redystrybucyjna i stabilizacyjna powinna być przede wszystkim domeną szczebla centralnego [Musgrave, 1959, s. 18-19].

Samodzielność finansową JST należy rozumieć jako: „określony zakres samodzielności decyzyjnej władzy samorządowej w kontekście możliwości prowadzenia 
własnej polityki fiskalnej na danym obszarze" [Poniatowicz, 2015, s. 15-16]. W sensie ekonomicznym przedmiotowa samodzielność odnosi się do zarządzania oraz samodzielności gospodarczej. W podejściu prawnym wyróżnia się aspekt ustrojowy oraz prawnofinansowy [Fojcik-Mastalska, Mastalski, 2013, s. 440].

W ekonomicznej literaturze przedmiotu identyfikuje się dwa zakresy samodzielności finansowej, tj.: prawnie zagwarantowaną możliwość samodzielnego decydowania o przeznaczeniu posiadanych środków (niezależnie od tego, czy są to dochody własne, czy też środki transferowe lub przychody budżetowe) oraz środków publicznych, które JST pozyskują we własnym zakresie [por. Jastrzębska, 2012].

Przedmiotowe rozróżnienie wiąże się natomiast $\mathrm{z}$ wyodrębnieniem samodzielności dochodowej oraz samodzielności wydatkowej. W „podejściu dochodowym” kluczowym zagadnieniem jest zagwarantowanie możliwości zwiększenia dochodów oraz pozyskiwanie ich z różnych źródeł, przy wykorzystaniu różnych metod. W „podejściu wydatkowym" istotny jest aspekt swobody w odniesieniu do kierunków i rodzajów ponoszonych wydatków" [Surówka, 2013, s. 22-25]. Należy podkreślić, że w analizie samodzielności finansowej problem samodzielności wydatkowej jest równie istotny, jak i dochodowej. Nie można zapominać jednak o tym, że: „formy, sposoby i przede wszystkim rozmiary wydatków uzależnione są od poziomu, struktury oraz sposobu pozyskiwania dochodów przez poszczególne j.s.t." [Ofiarski, 2012, s. 138]. Można więc stwierdzić, że gwarantem autonomii wydatkowej jest przede wszystkim samodzielność dochodowa samorządu.

Samodzielność dochodowa samorządu terytorialnego stanowi część szerszego pojęcia jakim jest samodzielność finansowa, jest jej - jak stwierdza A. Czarny: „niższym szczeblem uszczegółowienia” [Czarny, 2016, s. 42]. Wymaga nie tylko odpowiedniego poziomu dochodów, adekwatnego do realizowanych zadań, ale także możliwości swobodnego podejmowania decyzji w sprawach podatkowych, tj. zarówno władztwa podatkowego $\mathrm{w}$ zakresie określonych źródeł i możliwości oddziaływania na wysokość dochodów podatkowych, jak i możliwości ich administrowania. Tak rozumiana samodzielność dochodowa wymaga przekazania do dyspozycji JST tzw. dochodów własnych. W ujęciu teoretycznym, większy udział dochodów własnych w dochodach ogółem oznacza niewątpliwie większy zakres samodzielności dochodowej samorządu terytorialnego.

W sensie ekonomicznym samodzielność dochodowa JST należy więc rozumieć jako zagwarantowanie przez państwo wystarczających zasobów środków finansowych do realizacji zadań publicznych [Miemiec i in., 2013, s. 55]. Wyposażenie lokalnych społeczności jedynie w pakiet kompetencji, bez zapewnienia stosownych źródeł dochodów, godzi w istotę samorządu terytorialnego. Analogicznie należy ocenić przekazanie środków finansowych bez równoległego przyznania prawa do dysponowania zgromadzonymi zasobami [Zarys finansów..., 2011, s. 100]. Samodzielność dochodowa JST bezpośrednio łączy się więc z tzw. lokalnym władztwem podatkowym. Poza przekazaniem dochodów i władztwa do dysponowania nimi, w tym przypadku niezbędne jest także przekazanie uprawnień do ich kształtowania, a zwłaszcza kształtowania podatków stanowiących dochody własne jednostek samorządu. 
W odniesieniu do Polski najszerszy zakres samodzielności finansowej (dochodowej) posiadaja de facto gminy, ponieważ tylko te podmioty dysponuja prawem do gromadzenia dochodów własnych w postaci podatków i opłat lokalnych, chociaż jest ono wyraźnie ograniczone. Oznacza to, że lokalne władztwo podatkowe to domena tylko rad gmin i nie dotyczy organów innych JST. Można zatem stwierdzić, że w odniesieniu do powiatów i województw nie zostały zachowane standardy wynikające z przepisów EKST (art. 9 pkt. 3), według której przynajmniej część dochodów społeczności lokalnej powinna pochodzić z podatków, których wysokość społeczności te mają prawo ustalać (w zakresie wyznaczonym ustawa).

Ograniczone władztwo podatkowe przysługuje gminom tylko w ramach niektórych podatków lokalnych, tj. podatku od nieruchomości, rolnego, leśnego oraz od środków transportowych. Nie mają one żadnych uprawnień władczych w zakresie: podatku od spadków i darowizn, od czynności cywilnoprawnych oraz zryczałtowanego podatku dochodowego w formie karty podatkowej. W związku z tym, katalog źródeł dochodów własnych gminy jest dosyć obszerny i zróżnicowany. Jednak tylko w odniesieniu do niektórych $z$ nich możliwe jest prowadzenie własnej polityki podatkowej $i$ to także w bardzo ograniczonym zakresie, pozwalającym raczej na podejmowanie działań o charakterze indywidualnym, a nie systemowym [Ofiarski, 2012, s. 148].

Krytycznie, w kontekście władztwa podatkowego, należy ocenić dochodowa samodzielność finansowa powiatów, które nie zostały wyposażone we własne źródła dochodów z podatków lokalnych. Źródeł takich dochodów nie ma także samorząd wojewódzki, który w ramach podatkowych dochodów własnych, podobnie jak powiaty, uzyskał tylko udziały we wpływach CIT i PIT, zaliczane do podatków państwowych, które można uznać jedynie za ,atrapę” takiego źródła. Formalne jednak udziały w podatkach państwowych przypisane zostały do dochodów własnych poszczególnych szczebli samorządów, co z punktu widzenia teorii trudno jest uzasadnić [Miemiec, 2003].

Reasumując, należy stwierdzić, że samodzielność finansowa JST jest kategorią zmienna, ponieważ wpływa na nią wiele różnych czynników, takich jak: rozwój prawny, ekonomiczny, finansowy, społeczny oraz instytucjonalny państwa. Zmianom podlegają również prawne gwarancje tej samodzielności, których skuteczność uzależniona jest od polityki państwa w zakresie decentralizacji finansów publicznych. Ponadto na samodzielność finansowa wpływa koniunktura gospodarcza [Galiński, 2011].

\section{Samodzielność finansowa gmin w Polsce - good czy bad governance?}

Pomiar samodzielności finansowej, podobnie jak poziomu decentralizacji finansowej, nie jest łatwy. Jak dotychczas nie udało się ,skonstruować jednego, uniwersalnego miernika w tym zakresie, ale również poszczególne mierniki, skonstruowane w odniesieniu do dochodów i wydatków samorządowych, nie pozwalają na dokonanie oceny decentralizacji finansowej" [Poniatowicz, 2018, s. 99], a tym samym także samodzielności finansowej. Większość używanych mierników ma charakter 
ilościowy, co niewattpliwie uniemożliwia ocenę cech jakościowych badanego zjawiska. Nie oznacza to jednak, że powyższy pomiar należy uznać za bezprzedmiotowy.

Do oceny stopnia samodzielności finansowej jednostki najczęściej wykorzystuje się następujące mierniki: 1) dochody własne w relacji do dochodów ogółem, 2) dochody własne $z$ wyłączeniem udziałów w podatkach stanowiących dochody budżetu państwa w relacji do dochodów ogółem, 3) dochody podatkowe w relacji do dochodów ogółem, 4) wydatki inwestycyjne w relacji do wydatków ogółem itd. Do ukazania sytuacji finansowej w kontekście samodzielności finansowej gmin w Polsce autorzy zdecydowali się wybrać tylko niektóre z nich, bowiem celem analizy nie jest ukazanie wymiaru empirycznego samodzielności finansowej gmin w Polsce, a raczej próba oceny jej podstaw teoretycznych, prawnych i organizacyjnych w odniesieniu do koncepcji good governance.

TABELA 1

Udział dochodów własnych gmin w Polsce w dochodach ogółem* (\%)

\begin{tabular}{|l|c|c|c|c|c|c|c|c|c|c|}
\hline \multicolumn{1}{|c|}{ Nazwa } & $\mathbf{2 0 0 8}$ & $\mathbf{2 0 0 9}$ & $\mathbf{2 0 1 0}$ & $\mathbf{2 0 1 1}$ & $\mathbf{2 0 1 2}$ & $\mathbf{2 0 1 3}$ & $\mathbf{2 0 1 4}$ & $\mathbf{2 0 1 5}$ & $\mathbf{2 0 1 6}$ & $\mathbf{2 0 1 7}$ \\
\hline Polska & 58,2 & 54,9 & 52,7 & 53,1 & 52,9 & 54,5 & 55,4 & 55,8 & 51,6 & 50,8 \\
\hline Gminy miejskie & 68,5 & 65,1 & 62,5 & 62,2 & 60,8 & 62,0 & 62,5 & 62,9 & 60,1 & 59,7 \\
\hline Gminy miejsko-wiejskie & 51,0 & 48,0 & 46,5 & 47,4 & 48,3 & 50,1 & 51,1 & 51,3 & 45,7 & 44,6 \\
\hline Gminy wiejskie & 39,3 & 36,8 & 35,9 & 37,1 & 38,5 & 40,3 & 41,9 & 42,7 & 37,8 & 36,8 \\
\hline
\end{tabular}

* gminy łącznie z miastami na prawach powiatu

Źródło: obliczenia własne na podstawie: [Bank Danych Lokalnych].

TABELA 2

\begin{abstract}
Dochody własne gmin w Polsce z wyłączeniem udziałów w podatkach stanowiących dochody budżetu państwa w relacji do dochodów ogółem * $(\%)$
\end{abstract}

\begin{tabular}{|l|c|c|c|c|c|c|c|c|c|c|}
\hline \multicolumn{1}{|c|}{ Nazwa } & $\mathbf{2 0 0 8}$ & $\mathbf{2 0 0 9}$ & $\mathbf{2 0 1 0}$ & $\mathbf{2 0 1 1}$ & $\mathbf{2 0 1 2}$ & $\mathbf{2 0 1 3}$ & $\mathbf{2 0 1 4}$ & $\mathbf{2 0 1 5}$ & $\mathbf{2 0 1 6}$ & $\mathbf{2 0 1 7}$ \\
\hline Polska & 33,9 & 32,7 & 32,7 & 32,3 & 32,4 & 33,7 & 34,2 & 33,7 & 30,2 & 29,0 \\
\hline Gminy miejskie & 37,7 & 36,5 & 36,7 & 35,9 & 35,4 & 36,8 & 37,1 & 36,4 & 33,8 & 32,8 \\
\hline Gminy miejsko-wiejskie & 32,3 & 31,3 & 31,3 & 31,0 & 31,5 & 32,7 & 33,2 & 32,5 & 28,3 & 27,0 \\
\hline Gminy wiejskie & 25,9 & 25,0 & 25,0 & 25,2 & 26,1 & 27,3 & 28,3 & 28,2 & 23,9 & 22,7 \\
\hline
\end{tabular}

* gminy łącznie z miastami na prawach powiatu

Źródło: obliczenia własne na podstawie: [Bank Danych Lokalnych].

Z danych zawartych w tabelach 1 i 2 wynika, że zakres samodzielności finansowej gmin w Polsce, mierzony przytoczonymi wskaźnikami maleje, bowiem na przestrzeni badanego okresu zmniejszał się zarówno udział dochodów własnych gmin w dochodach ogółem, jak również udział dochodów własnych gmin z wyłączeniem dochodów z udziałów w podatkach państwowych w dochodach ogółem.

Idea demokratycznego państwa prawnego jest warunkiem „brzegowym” rozumianym per se i ten wymiar jakości rządzenia jest wyartykułowany bezpośrednio 
w Konstytucji RP. Demokratyczne państwo prawne jest standardem aksjologicznym współczesnego państwa jako takiego. Jego waga została ujęta w art. 2 Konstytucji RP w następującym brzmieniu: „Rzeczpospolita Polska jest demokratycznym państwem prawnym urzeczywistniającym zasady sprawiedliwości społecznej”. Wyraża się w takich cechach ustrojowych, jak: podział władzy, suwerenność narodu, niezawisłość sędziów, nadrzędność ustawy zasadniczej nad innymi aktami prawnymi itp. W odniesieniu do samodzielności finansowej JST w art. 165 ust. 2 Konstytucji RP podkreślono, że samodzielność jednostek samorządu terytorialnego podlega ochronie sądowej. $\mathrm{Z}$ kolei zgodnie $\mathrm{z}$ art. 167, jednostkom samorządu terytorialnego zapewnia się udział $\mathrm{w}$ dochodach publicznych odpowiednio do przypadających im zadań, a ich dochodami są dochody własne oraz subwencje ogólne i dotacje celowe z budżetu państwa. Źródła dochodów JST są określone w ustawie. Zmiany w zakresie zadań i kompetencji JST następują wraz z odpowiednimi zmianami w podziale dochodów publicznych.

Kolejnym aktem prawnym, który określa zasoby finansowe wspólnot lokalnych jest EKST. W jej świetle wspólnoty lokalne powinny mieć prawo do wystarczajacych własnych zasobów, które będą proporcjonalne do ich kompetencji przewidzianych przez Konstytucję lub prawo. Ponadto część zasobów finansowych wspólnot lokalnych powinna pochodzić z opłat i podatków lokalnych (ustalanych, w granicach prawa, przez same wspólnoty). Należy też chronić wspólnoty słabsze finansowo. Co więcej powinny być one konsultowane odnośnie do sposobów przydzielania im redystrybuowanych zasobów. Subwencje przyznawane wspólnotom lokalnym nie powinny być, co do zasady, przeznaczane na finansowanie projektów specyficznych. Ponadto w Polsce aktami prawnymi, które regulują sferę finansową JST, są: ustawa o finansach publicznych [Ustawa, 2009], ustawy samorządowe [Ustawa, 1990] oraz ustawa o dochodach JST [Ustawa, 2003].

Biorąc pod uwagę zakres samodzielności finansowej gmin w Polsce należy stwierdzić, że jest ona tylko w części wyrazem realizacji zasady demokratycznego państwa prawnego. Gminy w Polsce nie maja pełnej swobody w zakresie kształtowania dochodów własnych, zwłaszcza podatków. Można zatem dyskutować, czy zagwarantowano im konstytucyjne prawo do ich gromadzenia, a w związku z tym także do wydatkowania. Z formalnego punktu widzenia przedmiotowe kryterium wprawdzie zostało zagwarantowane, jednak ograniczone władztwo podatkowe, zaliczenie do dochodów własnych udziałów w podatkach państwowych, na które samorządy nie mają żadnego wpływu, wyraźnie wpływa na sytuację finansową gmin. Niewątpliwie, ustalając tak katalog dochodów dla poszczególnych szczebli samorządu w Polsce, zwłaszcza dotyczy to udziałów w podatkach państwowych, nie zapewniono „,...] wielkości środków finansowych odpowiednio do przekazanych im zadań (bardzo istotne zwiększenie zadań własnych, bez rzeczywistego zabezpieczenia finansowego, który wynikałby z odpowiedniej zmiany w podziale dochodów publicznych)" [Miemiec, 2003]. Co nie jest zgodne nie tylko ze standardami wynikającymi z EKST, ale także z zasadami Konstytucji RP (art. 167 i 168).

Kolejne kryterium poddawane analizie - przejrzystość - polega na publicznym szerokim dostępie do informacji na temat planowanych i zrealizowanych działań 
rządu i administracji. Wiąże się ona również z kontrolą korupcji. W odniesieniu do samodzielności finansowej sprawa staje się stosunkowo mało klarowna, bowiem o ile w statystykach publicznych możliwe jest odnalezienie informacji dotyczacych np. poziomu dochodów własnych (w relacji do dochodów ogółem, dochodów podatkowych w relacji do dochodów ogółem, wydatków inwestycyjnych do dochodów ogółem itd.) - to wszystko komplikuje się, gdy weźmie się pod uwagę rosnącą liczbę zadań, które w swoim zakresie powinny finansować/realizować gminy w Polsce. Należy zatem zadać pytanie, czy ustawodawca w swoich działaniach bierze pod uwage wpływ wprowadzanych zmian legislacyjnych (w zakresie finansowania zadań własnych oraz zadań zleconych) na przejrzystość funkcjonowania JST? Zgodnie a art. 166 ust. 1 Konstytucji RP, zadanie własne JST jest zadaniem publicznym, służącym zaspokajaniu potrzeb wspólnoty samorządowej. Może ono być realizowane w różnych formach, jest finansowane $\mathrm{z}$ dochodów własnych, a także z subwencji ogólnej. Zadania zlecone są finansowane przede wszystkim z dotacji celowej. Znamienne jest jednakże to, że gminy borykają się z ciąłym niedoborem środków finansowych w stosunku do liczby zadań, które realizują. Są zatem zmuszone do poszukiwania alternatywnych źródeł finansowania wydatków (moga pozyskiwać środki ze źródeł zagranicznych, emitować papiery wartościowe, czy też zaciagać kredyty i pożyczki, co jednak znacząco wpływa na ich płynność finansowa, ewentualnie na realizację nowych inwestycji w przyszłości). Ponadto, mimo że zasada przejrzystości jest zasadą ustawową w sferze finansów publicznych, gwarantowaną przepisami ustawy o finansach publicznych, wydaje się, że dane budżetowe nie sa prezentowane w sposób jasny i zrozumiały. W tym kontekście trudno też mówić o przejrzystości w zakresie samodzielności finansowej gmin. Z uwagi na sposób prezentacji danych finansowych, ale także w odniesieniu do działań państwa, które ową samodzielność określa w wymiarze prawno-organizacyjnym, w zasadzie nie jest możliwa pozytywna ocena realizacji zasady good governance.

Partnerstwo, jako istotny wymiar jakości rządzenia, obejmuje m.in. partycypację społeczna, możliwą dzięki istnieniu odpowiednich instytucji wspierających i stymulujących wspieranie podmiotów społecznych w relacjach z administracją i rządem/ władzami samorządowymi [Łopaciuk-Gonczaryk, Fałkowski, 2012]. W przypadku oceny wymiarów jakości rządzenia w samorządzie terytorialnym (w tym samodzielności finansowej) ewaluacji mogą podlegać zarówno działania rządu, jak i władz samorządowych. W odniesieniu do partnerstwa na poziomie samorządowym niewątpliwie jednym z jego aspektów jest realizacja budżetu partycypacyjnego (obywatelskiego). Jest to narzędzie współrządzenia, a także próba włączenia mieszkańców w rozwój lokalny. Nie jest to powszechne zjawisko w Polsce, jednakże obserwuje się rosnąca liczbę takich inicjatyw w kraju. Jak podkreślono w raporcie nt. „Pozyskanie nowych wskaźników dotyczacych realizacji ustug publicznych z zakresu partycypacji spotecznej" [2015] budżet partycypacyjny jest jedną z form wspierania udziału obywateli w procesie rządzenia. JST moga tradycyjne konsultować uchwałę budżetową w formie budżetu partycypacyjnego, co ma miejsce głównie w miastach, natomiast w gminach wiejskich popularnym mechanizmem jest fundusz sołecki. W świetle danych pochodzących z ww. raportu w 2014 r. z możliwości wydzielania budżetu obywatelskiego 
skorzystało jedynie 4\% badanych gmin. Liczba jednostek stosujących procedurę budżetu partycypacyjnego zwiększała się jednak dynamicznie. W 2012 r. tylko 3 gminy włączyły mieszkańców w kształtowanie budżetu w ten sposób, w kolejnym roku takich gmin było już 16. W 2014 r. na projekty w ramach budżetu obywatelskiego głosowali mieszkańcy 92 gmin, zaś w 2015 r. - 1713. Mechanizm ten szczególnie rozpowszechnił się przede wszystkim w dużych miastach - planując budżet na 2015 r. zastosowały go wszystkie miasta wojewódzkie i większość pozostałych miast na prawach powiatów. Dynamicznemu wzrostowi liczby gmin wprowadzających budżet partycypacyjny towarzyszył wzrost ogólnej kwoty wydzielonych na ten cel środków. W 2012 r. było to 5,3 mln zł, zaś w 2015 r. już 367,8 mln zł. Jednak udział budżetu partycypacyjnego w ogólnej kwocie budżetu gminy jest niski przeciętnie w 2014 r. stanowił 0,4\%. Interesujące są wartości wskaźników efektywności tego zjawiska - w 2014 r. średnia kwota przypadająca na mieszkańca w gminie posiadającej budżet partycypacyjny to $18 \mathrm{zł}$, natomiast średnia frekwencja w głosowaniu nad finansowaniem projektów złożonych przez mieszkańców wyniosła $11 \%$ [Pozyskanie nowych wskaźników..., 2015, s. 42-43]. Na podstawie analizy przytoczonych danych należy stwierdzić, że obywatele w Polsce maja znikomy udział w rządzeniu na poziomie samorządowym, co więcej, ze względu na brak oficjalnych źródeł informacyjnych na temat budżetu partycypacyjnego, nie ma możliwości przeprowadzenia kompletnej analizy w przedmiotowym zakresie. Warto jednak analizować problem z punktu widzenia zarówno samodzielności finansowej, jak również z perspektywy good governance. Wydaje się, że stosowanie budżetu partycypacyjnego może mieć związek z większą samodzielnością finansowa, a jednocześnie świadczy o poprawie stanu rządzenia w sferze samorządowej.

Możliwość włączania obywateli w proces planowania i wydatkowania funduszy z budżetu gminy została określona w Ustawie z dnia 21 lutego 2014 r. o funduszu sołeckim [Ustawa, 2014], na podstawie której gminy mogą wydzielać część budżetu, o której przeznaczeniu będa decydować mieszkańcy. Srodki w ramach funduszu sołeckiego można wydatkować tylko w tych gminach, które posiadaja sołectwa. Spośród 2174 gmin posiadających 4 sołectwa w nieco ponad połowie podjęto uchwałę o utworzeniu funduszu sołeckiego i wydatkowano z niego środki - w 2013 r. i 2014 r. odsetek ten był niemalże identyczny (54\% gmin). Liczba gmin, w których stworzono fundusz sołecki, wzrosła z 55\% w latach 2009-2013, do 65\% w 2015 r. i 68 w 2016 r. [Fundusze sołeckie zyyskuja popularność, 2016]. Przeciętny udział środków wydatkowanych w ramach funduszu sołeckiego stanowił 0,7\% w wydatkach ogółem z budżetu gminy, zarówno w 2013 r. jak i w 2014 r. Przeciętne wydatki zrealizowane $\mathrm{w}$ ramach funduszu sołeckiego w przeliczeniu na 1 mieszkańca wyniosły 29 zł w 2013 r. i 31 zł w 2014 r. Dostępność funduszu sołeckiego w skali kraju jest wyższa niż budżetu partycypacyjnego, jednak należy uwzględnić, że podczas gdy z pierwszego mechanizmu w ostatnich latach korzystała porównywalna liczba gmin,

3 Badania były prowadzone na próbie badawczej. 
to rozpowszechnienie budżetów partycypacyjnych wzrastało [Pozyskanie nonych wskaźników..., 2015, s. 49].

W kontekście partnerstwa warto także zwrócić uwagę na partnerstwo publicznoprywatne (PPP). Według danych na 30 czerwca 2018 r., publikowanych przez Ministerstwo Rozwoju, od 2009 r. w Polsce zawarto 126 umów w ramach PPP, a w bazie zamierzeń inwestycyjnych znajduje się 140 projektów. Jak wynika z analizy rynku PPP, najaktywniej działającymi w sferze PPP podmiotami publicznymi sa gminy, które łącznie zainicjowały 338 postępowań (63,06\% wszystkich postępowań), w tym 253 postępowania unikalne (62,31\% postępowań unikalnych). Wśród gmin prym wiodły gminy miejskie, które zainicjowały 159 postępowań (29,66\% wszystkich postępowań) oraz 121 postępowań unikalnych (29,80\% postępowań w tej grupie) [Analiza rynku ppp..., 2018]. Warto podkreślić, że skoro spośród wszystkich jednostek publicznych w Polsce instrument PPP jest najchętniej wykorzystywany przez gminy - to przedmiotowe jednostki maja świadomość korzyści płynących ze stosowania innowacyjnych rozwiązań w zakresie realizacji zadań publicznych. $Z$ jednej strony potrzebna jest pewna dojrzałość demokracji, wzajemne zaufanie partnerów: publicznego i prywatnego, z drugiej strony rozwojowi takich inwestycji może służyć dobra kondycja finansowa jednostek publicznych. PPP nie musi bowiem być jedynie remedium na brak środków finansowych. Może stać się także motorem rozwoju regionu, przy zastosowaniu najlepszych rozwiązań technologicznych, organizacyjnych i finansowych (dzięki partnerowi prywatnemu), a jednocześnie wpłynąc na podniesienie kompetencji jednostek publicznych w zakresie rządzenia.

Skuteczność i efektywność, jako wymiary jakości rządzenia, odnoszą się do rezultatów realizacji zadań państwa - warto zauważyć, że próbą stosowania tej zasady jest wdrażanie budżetu zadaniowego. Niestety dane dotyczące wdrażania budżetu zadaniowego przez samorządy lokalne w Polsce sa niekompletne. Agendy rządowe, śledząc rozwój instytucjonalny JST kolejno w 2009 r., w 2013 r. i 2017 r. - w ostatnim badanym okresie nie pokusiły się o zdiagnozowanie stanu zaawansowania wdrażania budżetu zadaniowego $\mathrm{w}$ polskim samorządzie terytorialnym [Barometr rožvoju instytucjonalnego..., 2013, 2017]. W porównaniu do badania z 2009 r., w badaniu przeprowadzonym w 2013 r. odnotowano nieco niższy odsetek samorzadów posiadających budżet zadaniowy. Może to być konsekwencja zadania pytania w inny sposób, ponieważ w ramach badania z 2009 r. pytano o wdrażanie budżetu zadaniowego, a w ramach badania z 2013 r. zapytano, czy w 2012 r. JST posiadała budżet zadaniowy. Niestety raport z 2017 r. nie zawiera porównywalnych danych, zatem nie ma możliwości oceny trendu rozwojowego w zakresie wykorzystywania budżetu zadaniowego przez gminy [Barometr rozpoju instytucjonalnego..., 2017]. Według dostępnych danych $\mathrm{z}$ wyżej wymienionych raportów, w okresie objętym badaniem, odsetek gmin posiadających budżet partycypacyjny utrzymywał się na stałym poziomie. W przypadku gmin wiejskich w 2009 r. było to $21 \%$, natomiast w 2013 r. - 17\%. Analogicznie dla gmin miejsko-wiejskich - 22\% i 18\%, natomiast dla gmin miejskich - 21\% i $18 \%$.

Wdrażanie budżetu zadaniowego w JST nie zależy jedynie od samodzielności finansowej jednostki, jednakże można przypuszczać, że wpływa ona na podejmo- 
wanie decyzji o jego stosowaniu. Wydaje się, że jednostki, posiadając własne zasoby finansowe i decydując o kierunkach ich przeznaczenia, będą chciały znać efekty realizowanych zadań publicznych, bowiem jest to tzw. budżet wydatków, a więc przedmiotowe narzędzie służy do zwiększania skuteczności i efektywności gospodarowania środkami finansowymi.

\section{Podsumowanie}

Good governance w samorządzie terytorialnym można uznać za dobro publiczne, ale również jako obszar wdrażania innowacji instytucjonalnych i organizacyjnych (budżet obywatelski, zadaniowy), co wyraźnie podkreślono w ramach dyskusji na Międzynarodowym Forum Regionów Forum Ekonomicznego [Sokołowski, 2017]. Warto niewatpliwie prowadzić analizy w przedmiotowym zakresie, ponieważ od jakości rządzenia zależy m.in. skuteczność i efektywność realizacji zadań publicznych, co nie jest bez znaczenia, gdy weźmie się pod uwagę stały dylemat niedoboru środków finansowych na finansowanie inwestycji samorządowych. Autorzy mają świadomość stopnia trudności, a także ułomności w zakresie prowadzenia analiz dotyczących jakości rządzenia w samorządzie terytorialnym, zwłaszcza w kontekście samodzielności finansowej gmin, jest to bowiem temat stosunkowo mało rozpoznany, zarówno w warstwie teoretycznej, jak również od strony empirycznej.

Na podstawie przeprowadzonych badań wykazano, że samodzielność finansowa gmin w Polsce ma charakter ograniczony. Co więcej, w zasadzie trudno jednoznacznie wskazać, że zarówno w aspekcie organizacyjno-prawnym, jak i ekonomicznym w tym kontekście spełnione sa kryteria good governance. O próbie poprawy jakości rządzenia w samorządzie terytorialnym mogą świadczyć inicjatywy takie, jak: budżet partycypacyjny, fundusz sołecki, partnerstwo publiczno-prywatne, czy też budżet zadaniowy, jednakże aktywność gmin w przedmiotowej sferze wciąż jest niewystarczająca.

Podsumowując można stwierdzić, że działania w zakresie poprawy jakości rządzenia znajdują się zarówno w gestii władz publicznych szczebla centralnego (ustawodawstwo/silne instytucje, działania administracji publicznej, publiczny kapitał społeczny), jak również podmiotów samorządowych. Trudno jest jednoznacznie ocenić, czy określony zakres samodzielności finansowej w większym stopniu pozwala na spełnianie kryteriów jakości rządzenia, jednakże w przekonaniu autorów warto prowadzić pogłębione analizy, które pozwolą wskazać na kierunek zależności między tymi zmiennymi.

\section{Literatura}

Analiza rynku ppp za okeres od 2009 r. do 30 czerwca 2018 r., 2018, Korbus B. (red.) https://www.ppp.gov.pl/Aktualnosci/Documents/2018_08_21_Analiza_rynku _ppp.pdf [data wejścia: 13.11.2018].

Bank Danych Lokalnych, Główny Urząd Statystyczny, Warszawa. 
Barometr rozwoju instytucjonalnego jednostek samorzqdu terytorialnego 2017, 2017, Frączkiewicz-Wronka L., Szemiako L., Gutta K., Ministerstwo Spraw Wewnętrznych i Administracji, http://ip.mswia.gov.pl/ip2/program-operacyjny-wied/ewaluacja/10563,Barometr-rozwoju-instytucjonalnego-jednostek-samorzadu-terytorialnego-2017.html [data wejścia 11.11.2018].

Barometr rozwoju instytucjonalnego jednostek samorzqdu terytorialnego, 2013, Piróg K., Leszczyńska B., Wolińska I., Ministerstwo Administracji i Cyfryzacji, Warszawa, http://www.ewaluacja.gov.pl/media/24923/Barometr\%20rozwoju\%20instytucj onalnego\%20JST.pdf [data wejścia: 10.11.2018].

Czarny A., 2016, Założenia i realizacja samodżielności dochodowej wybranych jednostek samorzqdu terytorialnego, „Folia Pomeranae Universitatis Technologiae Stetinensis, Oeconomica" 329(84)3.

Devas N., Alam M., Delay S., Oppong Koranteng R., Venkatachalam P., 2008, Financing Local Government, Commonwealth Secretariat, London.

EKST, Europejska Karta Samorządu Terytorialnego z 15 października 1985 r., Dz. U. z 1994 r. nr 124, poz. 607; sprostowanie: Dz. U. z 1996 r. Nr 154 poz. 1107.

European Governance - White Paper, Brussels, 25.7.2001, COM(2001) 428.

Filipiak B., 2011, Finanse samorzqdowe. Nowe wyzwania bieżqce i perspektywiczne, Wydawnictwo Difin, Warszawa.

Fojcik-Mastalska E., Mastalski R., 2013, Prawo finansowe, Wolters Kluwer Polska, Warszawa.

Fundusze soleckie zyskuja popularność, http://www.wspolnota.org.pl/aktualnosci/ aktualnosc/fundusze-soleckie-zyskuja-popularnosc [data wejścia: 13.11.2018].

Galiński P., 2011, Samodzielnośí finansowa jednostek samorzqdu terytorialnego - pojecie, determinanty, ocena, https://www.prawo.pl/samorzad/samodzielnosc-finansowa-jednostek-samorzadu-terytorialnego-pojecie-determinanty-ocena,79323.html [data wejścia: 15.11.2018].

Hausner J., 2015, Governance i jego konceptualne podstawy, [w:] Współzarzqdzanie publiczne, Hausner J., Mazur S. (red.), Wydawnictwo Naukowe Scholar, Warszawa.

Hausner J., Jessop B., Mazur S., 2016, Governance. Wybór tekstów klasycznych, Wydawnictwo Naukowe Scholar, Warszawa.

Good governance. The IMF's Role, 1997, International Monetary Fund, Washington, https://www.imf.org/external/pubs/ft/exrp/govern/govern.pdf [data wejścia: 14.11.2018].

Jakośc rzqdzenia w Polsce. Jak ja badać, monitorować i poprawiać, 2013, Wilkin J. (red.), Wydawnictwo Naukowe Scholar, Warszawa.

Jastrzębska M., 2012, Finanse jednostek samorzqdu terytorialnego, Wolters Kluwer Polska, Warszawa

Kańduła S., 2003, Samodzielność finansowa samorzadu gminnego w Polsce po 1993 roku, Wydawnictwo Akademii Ekonomicznej w Poznaniu, Poznań.

Kjaer A.M., 2004, Governance. Key Concepts, Polity Press, Wiley.

Konstytucja Rzeczypospolitej Polskiej z dnia 2 kwietnia 1997 r., Dz.U. 1997 Nr 78 poz. 483. 
Kornbereger-Sokołowska E., 2001, Samodzielność finansowa jednostek samorzadu terytorialnego w aktualnym systemie prawnym w Polsce, „Studia Iuridica”, XXXIX.

Kornberger-Sokołowska E., 2001a, Decentralizacja finansów publicznych a samodzielność finansowa jednostek samorzadu terytorialnego, Liber, Warszawa.

Kosikowski C., Salachna J., 2012, Finanse samorzqdowe. 580 pytań $i$ odpowiedzi, Wolters Kluwer Polska, Warszawa.

Levi-Faur D., 2012, The Oxford Handbook of governance, Oxford University Press Inc, New York.

Lopaciuk-Gonczaryk B., Fałkowski J., 2012, Kilka uwag na temat koncepcii dobrego rzadzenia z. punktu widzenia nowej ekonomii instytucjonalnej, nowej ekonomii politycznej i teorii kapitatu spotecznego, „Zarządzanie Publiczne”, nr 20(2).

Magnusson W., 2015, Local Self-Government and the Right to the City, Mc-Gill Queen's University Press, Montreal.

Miemiec M., Miemiec W., Sawicka K., 2013, Prawo finansów publicznych sektora samorzadowego, Wolters Kluwer, Warszawa.

Miemiec W., 2003, Opinia prawna do rzqdowego projektu ustany o dochodach jednostek samorzadu terytorialnego, Druk $\mathrm{nr}$ 1732, http://orka.sejm.gov.pl/rexdomk4.nsf/ Opwsdr?OpenForm\&1732 [data wejścia: 15.04.2017].

Musgrave R.A., 1959, The Theory of Public Finance: A Study in Public Economy, McGrawHill, New York.

Nye J.S., Donahue J.D., 2000, Governance in globalizing word. Visions for governance for the 21st century, Brooking Institutions Press, Cambridge Massachusetts.

Ofiarski Z., 2012, W ładžtwo daninowe oraz administrowanie podatkonymi žródtami dochodów wlasnych gmin - cay podziat kompetencji jest jeszcze potrzebny?, „Zeszyty Naukowe Administracji AJD w Częstochowie", nr 1.

Patrzałek L., 2010, Finanse samorzadu terytorialnego, Wydawnictwo Uniwersytetu Ekonomicznego we Wrocławiu, Wrocław.

Peters B.G., 2012, Is Governance for Evrybody? The Use and Abuse of Governance, [in:] Governance: Is It for Everyone?, Bissessar A.M. (ed.), Nova Science Publishers Inc., New York.

Piotrowska-Marczak K., 1997, Finanse lokalne w Polsce, PWN, Warszawa.

Poniatowicz M., 2015, Determinanty autonomii dochodowej samorzadu terytorialnego w Polsce, „Nauki o Finansach”, nr 1(22).

Poniatowicz M., 2018, Koncepgja federalizmu fiskalnego w systemie finansów samorzqdu terytorialnego, CeDeWu, Warszawa.

Posyskanie nowych wskaźnikón dotyczacych realizacji ustug publicznych z zakeresu partycypacji społecznej, Warszawa 2015, https://stat.gov.pl/files/gfx/portalinformacyjny/pl/ defaultstronaopisowa/5851/1/1/raport_partycypacja_spoleczna.pdf [data wejścia: 14.11.2018].

Rhodes R.A.W., 1996, The New Governance: Governing without Government, „Political Studies", no. XLIV

Rodrik D., 2000, Governance of economic globalization, [in:] Governance in globalizing word. Visions for governance for the 21st century, Nye J.S., Donahue J.D. (ed.), Brooking Institutions Press, Cambridge Massachusetts. 
Ruśkowski E., 2007, Finanse lokalne po akcesji, Wolters Kluwer, Warszawa.

Sadioglu U., Dede K., 2016, Theoretical Foundations and Discussions on the Reformation Process in Local Government, IGI Global, Hershey.

Sokołowski W., 2017, Projekt: Innowacyjny samorzad terytorialny w Polsce, http://www. forum-ekonomiczne.pl/wp-content/uploads/2018/11/Projekt_Innowacyjny_ Samorzad_Terytorialny_w_Polsce.pdf [data wejścia: 14.11.2018].

Surówka K., 2013, Samodzielność finansowa samorz̨du terytorialnego w Polsce, Polskie Wydawnictwo Ekonomiczne, Warszawa.

Swianiewicz P., 2011, Finanse samorzadowe, koncepcje, realizacja, polityki lokalne, Municipum, Warszawa.

The World Bank, 1992, Governance and Developement, http://documents.worldbank. org/curated/en/604951468739447676/pdf/multi-page.pdf [data wejścia: 10.11. 2018].

Ustawa z dnia 8 marca 1990 r. o samorządzie gminnym, Dz. U. 1990 Nr 16 poz. 95.

Ustawa z dnia 13 listopada 2003 r. o dochodach jednostek samorządu terytorialnego, Dz. U. 2003 Nr 203 poz. 1966.

Ustawa z dnia 27 sierpnia 2009 r. o finansach publicznych, Dz. U. 2009 Nr 157 poz. 1240.

Ustawa z dnia 21 lutego 2014 r. o funduszu sołeckim, Dz. U. 2014 poz. 301.

What is good governance? https://www.unescap.org/sites/default/files/good-governance.pdf [data wejścia: 10.11.2018].

Williamson O.E., 1996, The mechanisms of governance, Oxford University Press, New York.

Zarys finansów publicznych i prawa finansowego, 2011, Wójtowicz W. (red.), Wolters Kluwer Polska, Warszawa. 